\title{
Evidence for a magmatic origin for Carlin-type gold deposits: isotopic composition of sulfur in the Betze-Post-Screamer Deposit, Nevada, USA
}

Received: 28 June 2004 / Accepted: 29 March 2004/Published online: 28 May 2005

(C) Springer-Verlag 2005

\begin{abstract}
We report here new sulfur isotope analyses from the Betze-Post-Screamer deposit, the largest Carlin-type gold deposit in the world. Carlin-type deposits contain high concentrations of arsenic, antimony, mercury, tellurium and other elements of environmental interest, and are surrounded by large volumes of crust in which these elements are also enriched. Uncertainty about the source of sulfur and metals in and around Carlin-type deposits has hampered formulation of models for their origin, which are needed for improved mineral exploration and environmental assessment. Previous studies have concluded that most Carlin-type deposits formed from sulfide sulfur that is largely of sedimentary origin. Most of these studies are based on analyses of mineral separates consisting of pre-ore diagenetic pyrite with thin overgrowths of ore-related arsenian pyrite rather than pure, ore-related pyrite. Our SIMS spot analyses of ore-related pyrite overgrowths in the Screamer zone of the Betze-Post-Screamer deposit yield $\delta^{34} \mathrm{~S}$ values of about -1 to $4 \%$ with one value of about $7 \%$. Conventional analyses of realgar and orpiment separates from throughout the deposit yield $\delta^{34} \mathrm{~S}$ values of about $5-7 \%$ with one value of $10 \%$ in the Screamer zone. These results, along with results from an earlier SIMS study in the Post zone of the deposit and phase equilibrium constraints, indicate that early arsenian pyrite were formed from fluids of magmatic origin with variable contamination from sulfur in Paleozoic sedimentary rocks. Later arsenic sulfides were formed from solutions to which sulfur of sedimentary origin had been added. The presence of Paleozoic sedimentary sulfur in Carlin-type deposits does not require direct
\end{abstract}

Editorial handling: G. Beaudoin

S. E. Kesler $(\bowtie) \cdot Z$. Ye

Department of Geological Sciences, University of Michigan, Ann Arbor, MI, USA, 48109

E-mail: skesler@umich.edu

L. C. Riciputi

Oak Ridge National Laboratory MS6365, PO Box 2008, Oak Ridge, TN 37831, USA involvement of hydrothermal solutions of sedimentary origin. Instead, it could have been added by magmatic assimilation of Paleozoic sedimentary rocks or by hydrothermal leaching of sulfur from wall rocks to the deposit. Thus, the dominant process delivering sulfur, arsenic, gold and mineralizing fluids to Carlin-type systems and their surrounding country rocks was probably separation of fluids from a magmatic source.

Keywords Sulfur isotope - Carlin-type deposit · Gold · arsenian pyrite $\cdot$ Nevada

\section{Introduction}

Carlin-type deposits, which are among the largest hydrothermal gold deposits in the world, are also enriched with arsenic, antimony and mercury (Arehart 1996; Hofstra and Cline 2000). In northern Nevada and southern China, these elements form large anomalous zones that extend outward for miles from the deposits, forming locally important environmental contamination (Fig. 1). The source of these elements is controversial, as is the nature of the hydrothermal systems that concentrated them. Models involving meteoric, magmatic, metamorphic and basinal hydrothermal systems have been proposed for Carlin-type deposits (Radtke et al. 1980; Bakken and Einaudi 1986; Sillitoe and Bonham 1990; Seedorff 1991; Kuehn and Rose 1995; Ilchik and Barton 1997; Hofstra et al. 1999; Ressell et al. 2000; Hofstra and Cline 2000; Emsbo et al. 2003), but application of these models has been limited by a lack of evidence for the source of elements that are enriched in the deposits.

Sulfur is the most abundant introduced element in Carlin-type deposits, and knowledge of its isotopic composition should help discriminate among these genetic models and improve our understanding of processes that form such large-scale geochemical anomalies in the upper crust. Previous sulfur isotope analyses of 
pyrite, marcasite and arsenopyrite from these deposits have yielded $\delta^{34} \mathrm{~S}$ values between about $0 \%$ and $17 \%$, which have been interpreted to indicate a largely sedimentary origin for the sulfur in Carlin-type deposits (Hofstra and Cline 2000; Emsbo et al. 2003). Most of these analyses were carried out on physical separates of variable purity consisting of pre-ore pyrite grains of diagenetic or other origin with thin overgrowths of orerelated arsenian pyrite. Lack of information on the proportions of pre-ore and ore-related pyrite in these separates limits their usefulness as indicators of the isotopic composition of sulfide introduced during mineralization.

In an effort to resolve these complications, Kesler et al. (2003a) determined the sulfur isotope composition of sulfide sulfur that was leached chemically from ore and barren samples that had been analyzed for gold and arsenic. This study, which was carried out on samples from the Screamer section of the Betze-Post deposit (Fig. 1), the largest Carlin-type deposit in the world, showed that samples containing less than $200 \mathrm{ppb} \mathrm{Au}$ (i.e. barren samples) had $\delta^{34} \mathrm{~S}$ values ranging from -13 to $16 \%$ with no significant mode, whereas samples containing more than $200 \mathrm{ppb} \mathrm{Au}$ (mineralized samples) had approximately the same range of $\delta^{34} \mathrm{~S}$ values, but a strong mode between $-1 \%$ and $2 \%$. Because $\mathrm{Fe}-\mathrm{S}$

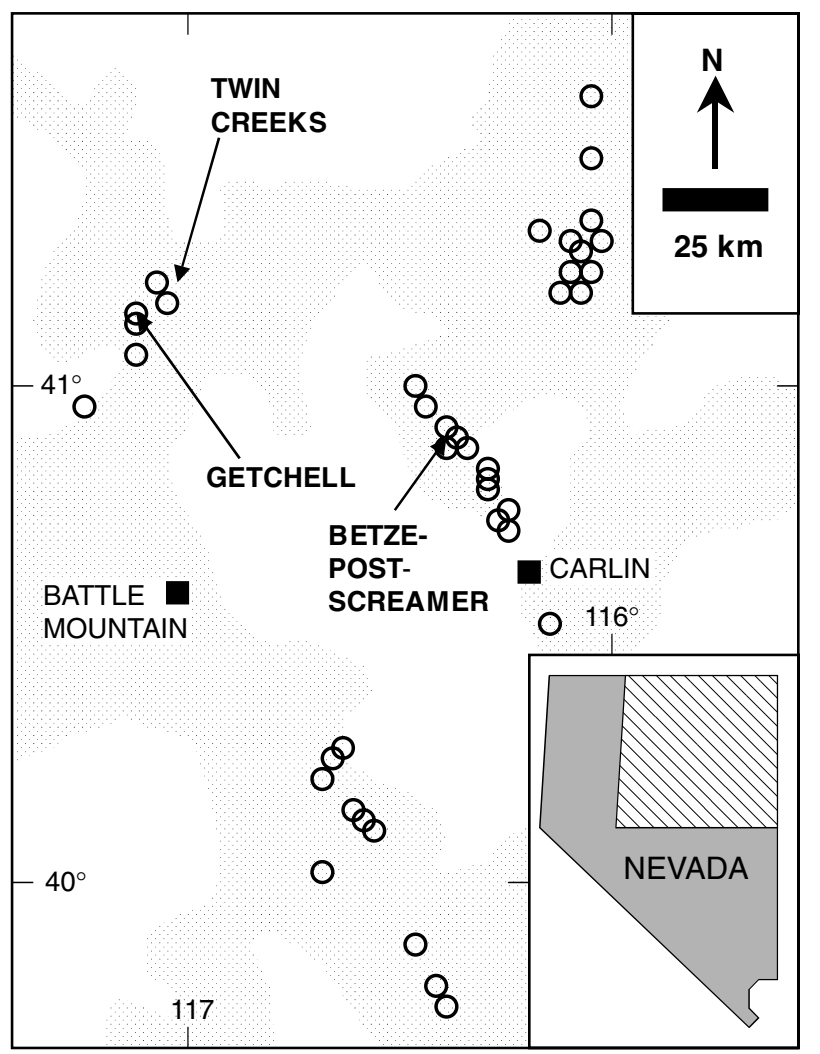

Fig. 1 Relation between Carlin-type deposits and areas enriched in arsenic (shown here as above-average arsenic values from 4,300 stream sediment samples) in northern Nevada (modified from Kotlyar et al. 1998) relations showed that sulfur had been added to the deposit, this result was interpreted to indicate that orerelated sulfur had an isotopic composition of about $0 \%$, which was interpreted to be of magmatic origin (Kesler et al. 2003a).

This study reports additional sulfur isotope analyses made to evaluate this conclusion. The isotopic composition of main-stage ore fluids was determined by spot analysis of arsenian pyrite using ion probe (SIMS) methods and the isotopic composition of late-stage, arsenic-bearing fluids was determined by analysis of arsenic sulfide mineral separates. The Screamer section of the Betze-Post-Screamer deposit, which was the focus of this study, is a continuous, tabular ore zone that extends about $2 \mathrm{~km}$ from Post in the east where it has a greater vertical extent, through Betze in the center to Screamer in the west (Fig. 2). Mineralization is concentrated in the wispy member of the Popovich Formation, near its contact with the underlying Silurian-Devonian Roberts Mountains Formation (Bettles 1989; Ye et al. 2002; Kesler et al. 2003a). Small but locally significant amounts of ore are also found in the Jurassic-age Goldstrike stock, which crops out on the southeast edge of the deposit (Emsbo et al. 2000). Most gold mineralization at Betze-Post and elsewhere along the Carlin trend is thought to have formed between $42 \mathrm{Ma}$ and $30 \mathrm{Ma}$, although at least four earlier hydrothermal events have affected the area since early Paleozoic time (Arehart et al. 1993b, 2003; Hofstra et al. 1999; Emsbo et al. 2003).

\section{Analytical methods}

SIMS sulfur isotope analyses were carried out on pyrite from two gold-rich drill core samples (BZ-995-1194 and SJ-323C-1326) that represent the range of geologic settings and As:Au ratios at Screamer (Table 1, Fig. 3). Pyrite in BZ-995-1194 is hosted largely by fine-grained, carbonate sediment, and forms disseminated small grains with a lath-shaped habit typical of marcasite from which it might have inverted (Fig. 4a). The disseminated pyrite has been partly to totally replaced by arsenian pyrite, which mantles the grains. Pyrite in SJ-323-1326 is hosted by a calcite-quartz vein containing coarsegrained, arsenic-poor pyrite with overgrowths of arsenian pyrite that has not replaced much of the early pyrite (Fig. 4b). Bulk chemically leached sulfide sulfur in both samples has slightly positive $\delta^{34} \mathrm{~S}$ values (Table 1).

SIMS measurement of ${ }^{34} \mathrm{~S} /{ }^{32} \mathrm{~S}$ ratios of these arsenian pyrites were made with the Cameca $4 \mathrm{f}$ at Oak Ridge National Laboratory, using a $\mathrm{Cs}^{+}$primary beam, monitoring $\mathrm{S}^{-}$secondary ions with extreme energy filtering of $300 \mathrm{eV}$, and using a normal incidence electron gun to compensate for sample charging as described by Riciputi (1996), Paterson et al. (1997), McSween et al. (1997) and Riciputi et al. (1998). Pyrite, pyrrhotite, and chalcopyrite standards were used to correct for instrumental mass fractionation. Precision and accuracy of the data reflect errors arising from the counting statistics of 
Fig. 2 a Schematic geologic map of the Betze-Post-Screamer deposit showing location of samples from the Screamer area analyzed in this study (SJ-323, BZ-995) and samples from the Post area analyzed by Arehart et al. (1993a, 1993c). Samples 1343, 1749 and 1751 at Post are hosted by igneous rocks that are not seen on the line of section used here. b Schematic geologic cross section through the Betze-Post-Screamer area showing general form of the ore zone and approximate location of samples used in this study

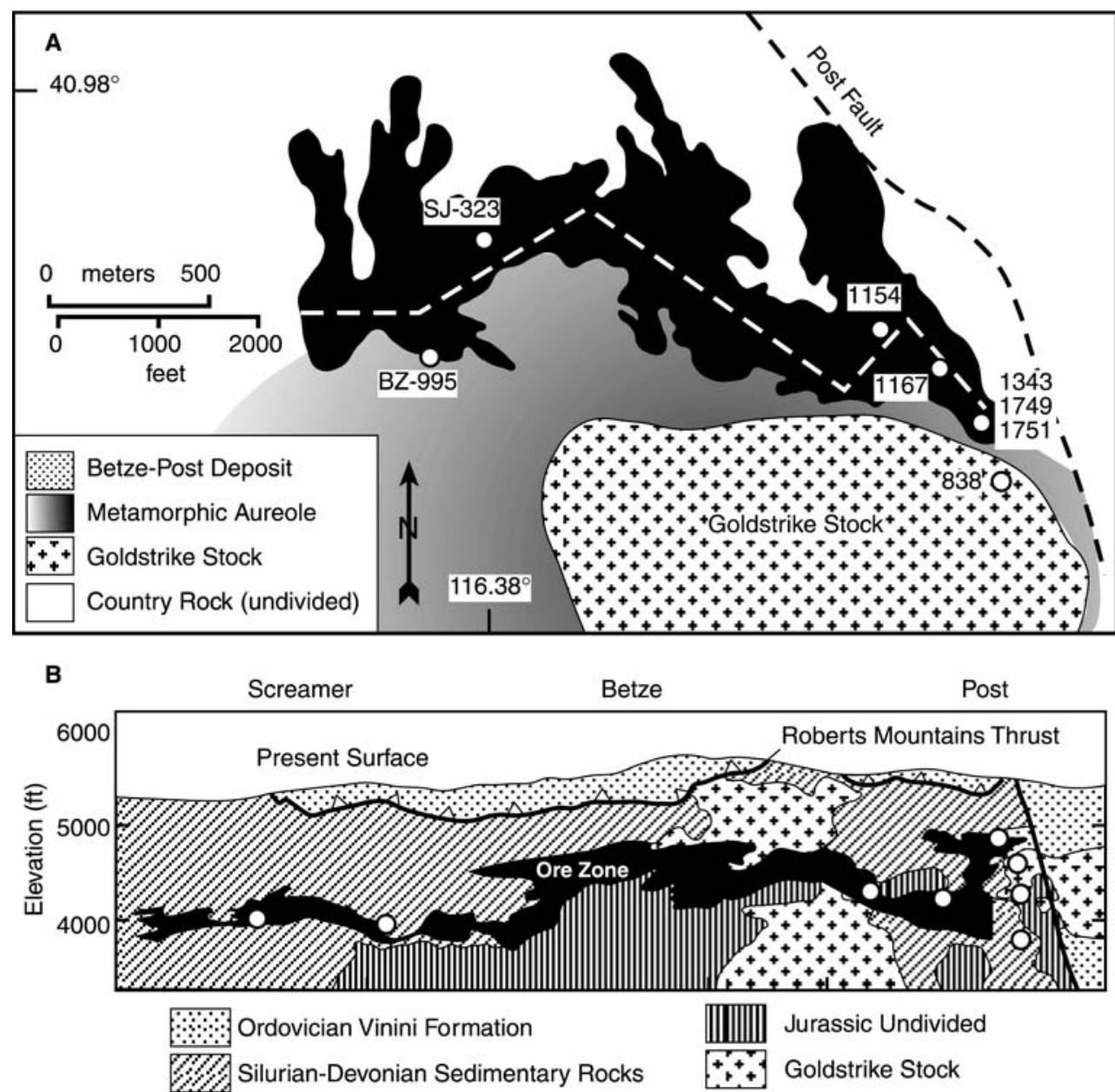

each analysis, dead-time corrections, uncertainty in composition of standard minerals, and calibration to the standard mineral. Internal precision of these analyses based on counting statistics of the analysis itself was around $\pm 0.5 \%$ (1SD). SIMS analyses of a laboratory arsenopyrite with a reported $\delta^{34} \mathrm{~S}$ value of $+1.6 \%$ yielded a value of $+2.5 \%$. This standard was also used to determine As/S ratios of sample spots to confirm that sulfur isotope analyses were carried out on arsenian pyrite.

Bulk sulfur isotope analyses were carried out on hand-picked separates of realgar and orpiment from throughout the Betze-Post-Screamer system. Large grain size of these minerals resulted in pure separates with almost no contamination from pyrite or wall rock. Analyses were carried out at Queen's University under the supervision of T.K. Kyser using methods reviewed in Kesler et al. (2003a).

\section{Analytical results}

SIMS analyses of pyrite in the two gold-rich samples yield $\delta^{34} \mathrm{~S}$ values between about -0.9 and $3.6 \%$, with one value of $7.1 \%$ (Table 1, Fig. 5a). The unusually high $\delta^{34} \mathrm{~S}$ value of $7.1 \%$ was obtained from a small zone of porous pyrite rather than the more typical overgrowths of arsenian pyrite on diagenetic pyrite, and could have been contaminated by sulfur from another source, possibly organic matter or sulfates related to weathering. Arsenian pyrite overgrowths were distinguished from the diagenetic pyrite that they covered on the basis of both appearance (Fig. 4) and As/S ratio as determined during the SIMS analysis. $\delta^{34} \mathrm{~S}$ values of cores and rims identified in this way show a wide spread, with $\delta^{34} \mathrm{~S}$ values of the cores being slightly lower, on average, than the rims (Fig. 5b). Excluding the high value of $7.1 \%$, there is a weak correlation between increasing $\mathrm{As} / \mathrm{S}$ ratios and $\delta^{34} \mathrm{~S}$ values. These results suggest that most orerelated arsenian pyrite in these samples has $\delta^{34} \mathrm{~S}$ values of about $1-3 \%$, which is in very good agreement with the $\delta^{34} \mathrm{~S}$ values of -1 and $2 \%$ reported by Kesler et al. (2003a) for sulfide leached from gold-rich samples.

$\delta^{34} \mathrm{~S}$ values for arsenic sulfides in the deep part of the Post deposit range from 5.3\% to $5.8 \%$ for orpiment and $6.0 \%$ to $6.7 \%$ for realgar (Table 1, Fig. 5a). Realgar from one vein in the Screamer section has a higher $\delta^{34} \mathrm{~S}$ value of $9.9 \%$ (Table 1$)$. 
Table 1 Sulfur isotope compositions measured by SIMS for core and overgrowth pyrite from the Screamer zone of the Betze-Post deposit (Fig. 1). Also shown are gold and arsenic contents of hand samples containing these pyrites, as well as sulfur isotopic compositions of chemically leached sulfide sulfur in the hand sample from Kesler et al. (2003a)

\begin{tabular}{lll}
\hline Sample/Spot & $\delta^{34} \mathrm{~S}(\% \mathrm{oo})$ & $\mathrm{As} / \mathrm{S}$ \\
\hline SJ-323C-1326 (154 ppm Au, 3900 ppm As) & \\
Hand sample & 3.3 & $5.2 \mathrm{E}-3$ \\
1-1-X-rim & 2.5 & $4.9 \mathrm{E}-4$ \\
1-1-1-core + rim & 0.3 & $1.9 \mathrm{E}-3$ \\
1-1-2-core & 0.6 & $4.1 \mathrm{E}-5$ \\
1-3-01-core? & 1.4 & $4.8 \mathrm{E}-3$ \\
1-3-02-core? & 0.7 & $4.1 \mathrm{E}-3$ \\
1-4-1-core & 1.0 & $5.1 \mathrm{E}-6$ \\
1-4-2-rim & 1.3 & $4.8 \mathrm{E}-3$ \\
1-4-X-core & 0.2 & $5.1 \mathrm{E}-6$ \\
1-4-X-core? & -0.1 & $3.9 \mathrm{E}-5$ \\
1-4-X-core/rim? & 1.2 & $4.6 \mathrm{E}-3$ \\
1-6-01-core & 0.2 & $1.3 \mathrm{E}-5$ \\
1-7-01-porous & -0.6 & $4.7 \mathrm{E}-5$ \\
BZ-995C-1194 (42 ppm Au, $6200 \mathrm{ppm} \mathrm{As)}$ & \\
Hand sample & 4.7 & $2.8 \mathrm{E}-3$ \\
2-2-1-rim & 1.6 & $1.3 \mathrm{E}-2$ \\
2-2-2-core + rim & -0.3 & $2.8 \mathrm{E}-2$ \\
2-2-4-core & -0.9 & $2.9 \mathrm{E}-4$ \\
2-2-X-core? & 3.6 & $4.4 \mathrm{E}-4$ \\
2-3-X-core? & 2.6 & $3.5 \mathrm{E}-3$ \\
2.3-X-rim? & 3.0 & $1.2 \mathrm{E}-2$ \\
2-3-X-rim? & 0.6 & $1.1 \mathrm{E}-2$ \\
2-4-X-core & 2.5 & $4.0 \mathrm{E}-3$ \\
2-4-X-rim & 2.9 & $1.4 \mathrm{E}-2$ \\
2-5-X-porous & 7.1 & $1.1 \mathrm{E}-3$ \\
\hline
\end{tabular}

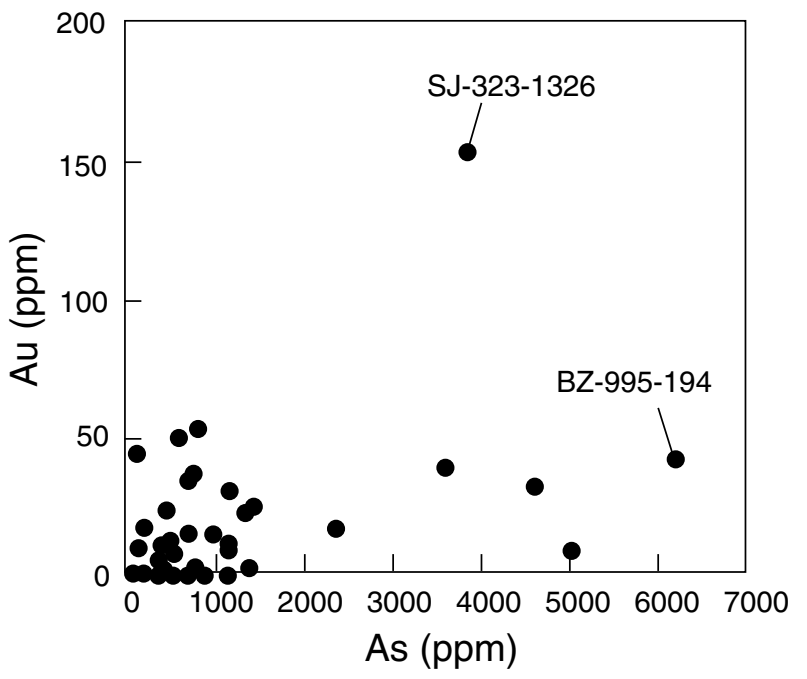

Fig. 3 Gold and arsenic contents of Screamer samples showing composition of the two samples (SJ-323-1326, BZ-995-1194) analyzed by SIMS methods in this study

\section{Isotopic composition of sulfur in the Betze-Post-Screamer ore fluid}

The $\delta^{34} \mathrm{~S}$ values of about -1 to $3 \%$ estimated from our combined SIMS and leachate analyses for ore-related pyrite in the Screamer zone are at the low end of the range of 0 to $17 \%$ obtained for ore-related pyrite from Carlin-type deposits (Hofstra and Cline 2000). As noted above, most of these analyses are from pyrite separates that are contaminated by variable amounts of diagenetic pyrite. Our SIMS analyses from Screamer also differ from SIMS analyses of ore-related arsenian pyrite and marcasite in the Post part of the Betze-Post-Screamer deposit, which are more variable and extend to higher values (Arehart et al. 1993a) (Fig. 6). Four of the Post samples analyzed by SIMS are from igneous rocks and might contain pyrite of Jurassic age (Arehart et al. 1993a; Emsbo et al. 2000). Pyrite separates from veins and disseminations thought to be of Jurassic age in the Goldstrike stock have $\delta^{34} \mathrm{~S}$ values as high as $15.6 \%$, which could account for some or all the high SIMS $\delta^{34} \mathrm{~S}$ values in the igneous samples (Arehart et al. 1993a; Emsbo et al. 2003). Two of the SIMS samples from Post are from pyrite in sedimentary rocks, however, and they also yielded high $\delta^{34} \mathrm{~S}$ values ranging from $2 \%$ to $20 \%$. If these pyrites are indeed part of the Carlin-type mineralization, as seems likely, an additional explanation is required for their high $\delta^{34} \mathrm{~S}$ values. The most likely explanation involves remobilization of sulfur from the Jurassic Goldstrike stock or from diagenetic and sedex sulfur in the sedimentary rocks during Carlin mineralization. SIMS, mineral separate and leachate analyses show that diagenetic and sedex sulfides in Silurian and Devonian sedimentary rocks in the Carlin area have $\delta^{34} \mathrm{~S}$ values as high as $19 \%$, and sedex barite has $\delta^{34} \mathrm{~S}$ values of 21.7-51\% (Radtke et al. 1980; Arehart et al. 1993a; Emsbo et al. 2003; Kesler et al. 2003). That some of this sulfide was almost certainly remobilized during Carlintype mineralization is shown by the large range of $\delta^{34} \mathrm{~S}$ values, $-21.2 \%$ to $11.7 \%$, obtained for pyrite in veins at Screamer (Kesler et al. 2003a, Table 3).

The lack of a wide range of $\delta^{34} \mathrm{~S}$ values in our leachate and SIMS analyses from the Screamer section of the Post-Betze-Screamer deposit suggests that similar contamination was not as extensive in this area. This difference in degree of contamination in the Post and Screamer sections of the deposit is probably related to the fact that hydrothermal alteration, including kaolinization, decarbonatization and silicification, is more intense and pervasive in the Post area (Arehart et al. 1993b; Ferdock 1997; Ye et al. 2002). Ore in Post area also has a greater vertical extent, reaches farther down in the stratigraphic section, and is partly within the Goldstrike stock (Fig. 2). It is important, in this regard, to recognize that the main direction of flow of ore fluids at Betze-Post-Screamer was probably upward rather than westward from the Post fault. Detailed cross sections of the Screamer ore body show that it is richest around steep faults in all areas, rather than gradually diminishing in grade toward to the west and that these faults are not rooted in the Goldstrike stock (Kesler et al. 2003a, Fig. 2). Thus, fluids entering the Screamer zone probably did not pass through the Post zone and would not be expected to reflect the greater wall rock contamination that took place in this area. 
Fig. 4 a, b SEM-BSE images of arsenian pyrite from SJ-3231326 (a, b) and BZ-995-1194 (c, d) showing distribution of arsenic-rich areas (lighter shade) and location of analyzed spots listed in Table 1
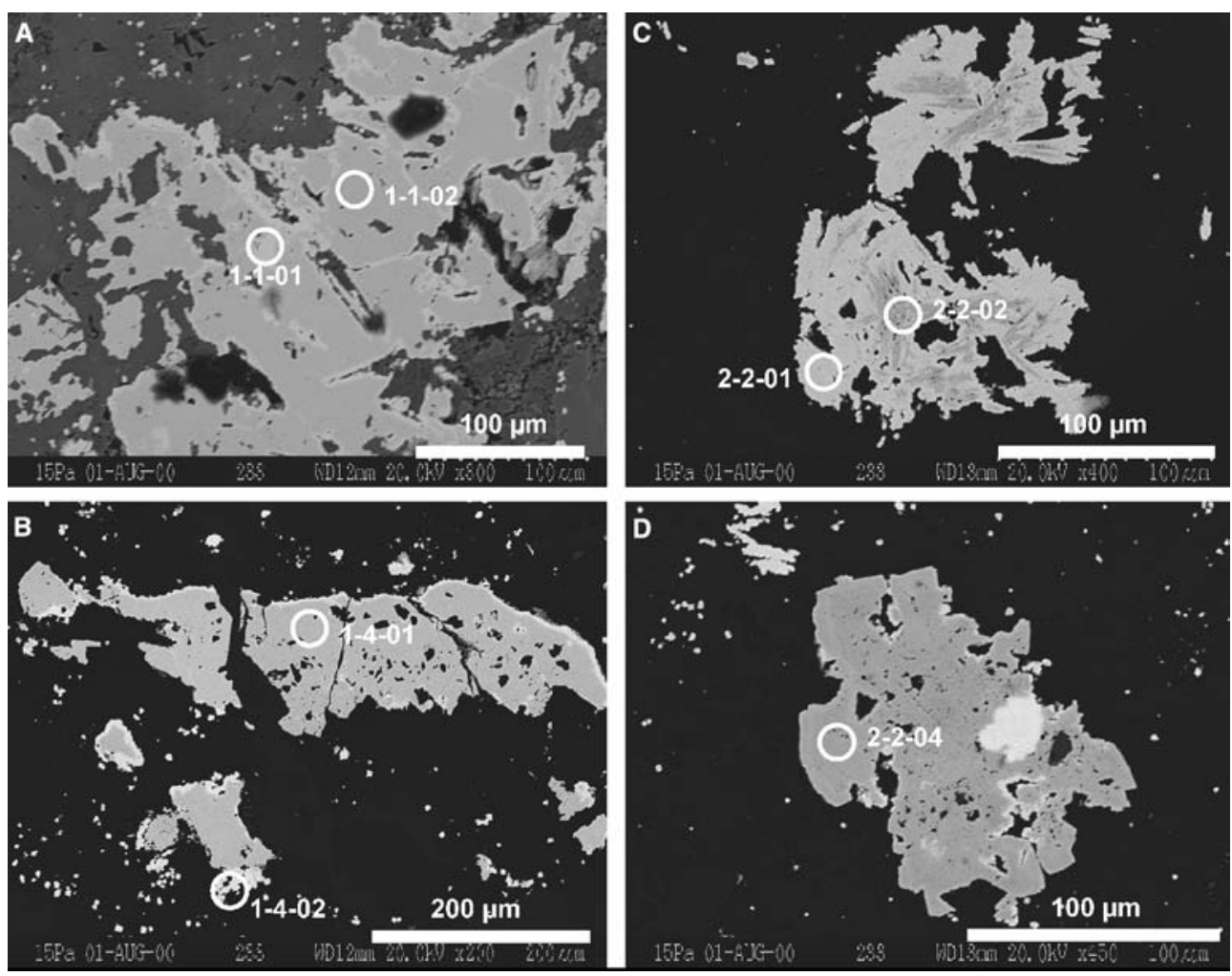

Table 2 Sulfur isotope composition of arsenic sulfide separates from the Betze-Post-Screamer deposit

\begin{tabular}{lll}
\hline Sample & Location & $\delta^{34} \mathrm{~S}(\%)$ \\
\hline DP-03-03-OR & Deep Post & 5.7 \\
DP-03-02-RL & Deep Post & 6.0 \\
DP-03-03-RL & Deep Post & 6.0 \\
DP-03-04-OR & Deep Post & 5.3 \\
DP-03-04-RL & Deep Post & 6.3 \\
DP-03-05-RL & Deep Post & 6.7 \\
P-175-1327-OR & Deep Post & 5.5 \\
P-175-1330-OR & Deep Post & 5.8 \\
P-208-1584-OR & Deep Post & 5.5 \\
SJ-552-1093-RL & Screamer & 9.9 \\
\hline
\end{tabular}

Analyses carried out at Queen's University under the supervision of T.K.Kyser

Our sulfur isotope analyses for arsenic sulfides can also be compared to analyses from the eastern (Post) part of the Betze-Post-Screamer. For realgar and orpiment, our analyses, which range from $5.3 \%$ to $6.7 \%$, are very similar to those from Post, which range from 3.8\%o to $6.6 \%$ (Emsbo et al. 2003). Emsbo et al. (2003) reported $\delta^{34} \mathrm{~S}$ values of $7.9 \%$ from Rodeo and $9.2 \%$ from Golden April, which are similar to our value of $9.9 \%$ from Screamer. Because the arsenic sulfides are coarsegrained and not intergrown with other sulfides, these isotopic compositions do not require SIMS analyses or efforts to distinguish between analyses representing ore fluids and those related to earlier sulfides.

These relations indicate that our combined SIMS and leachate analyses of -1 to $3 \%$ for $\delta^{34} \mathrm{~S}$ values of ore- related pyrite from the Screamer zone provide the best estimate of the isotopic composition of the Betze-PostScreamer mineralizing fluid. For $200^{\circ} \mathrm{C}$, Carlin-type hydrothermal solutions in which sulfur is dominated by $\mathrm{H}_{2} \mathrm{~S}$, average $\delta^{34} \mathrm{~S}$ values of sulfur in the ore fluid would need to be about $0 \%$ to deposit pyrite with $\delta^{34} \mathrm{~S}$ values of -1 to $3 \%$ o (Ohmoto and Rye 1979). Estimation of the isotopic composition of parent fluids is more difficult for arsenic sulfides because experimental fractionation data are not available. Fractionation data for cinnabar are commonly used to interpret isotopic data for arsenic sulfides, even though its crystal structure is significantly different (Hofstra et al. 1999). On that basis, arsenic sulfides with $\delta^{34} \mathrm{~S}$ values of about $5-10 \%$ that are observed at Betze-Post-Screamer require ore fluids containing $\mathrm{H}_{2} \mathrm{~S}$ with $\delta^{34} \mathrm{~S}$ values of about 9 to $14 \%$ (Ohmoto and Rye 1979).

\section{Sources of sulfur in the Betze-Post-Screamer ore fluid}

Our new estimates for the average $\delta^{34} \mathrm{~S}$ value of sulfur in fluids that formed pyrite and arsenian sulfides differ in two ways from earlier surveys based largely on mineral separates (Hofstra et al. 1997; Hofstra and Cline 2000; Emsbo et al. 2003). First, we estimate that the fluid that deposited gold-bearing arsenian pyrite had an average $\delta^{34} \mathrm{~S}$ value of about $0 \%$ rather than the $10 \%$ needed to account for $\delta^{34} \mathrm{~S}$ values of 0 to $17 \%$ seen in the pyrite separates (Hofstra and Cline 2000; Emsbo et al. 2003). Second, although our estimate that sulfur in fluids that 
A Arsenic Sulfides Bulk Analyses

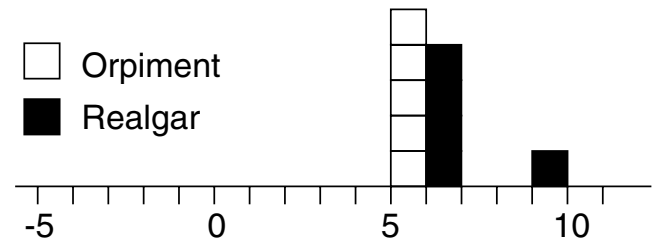

Arsenian Pyrite SIMS Analyses
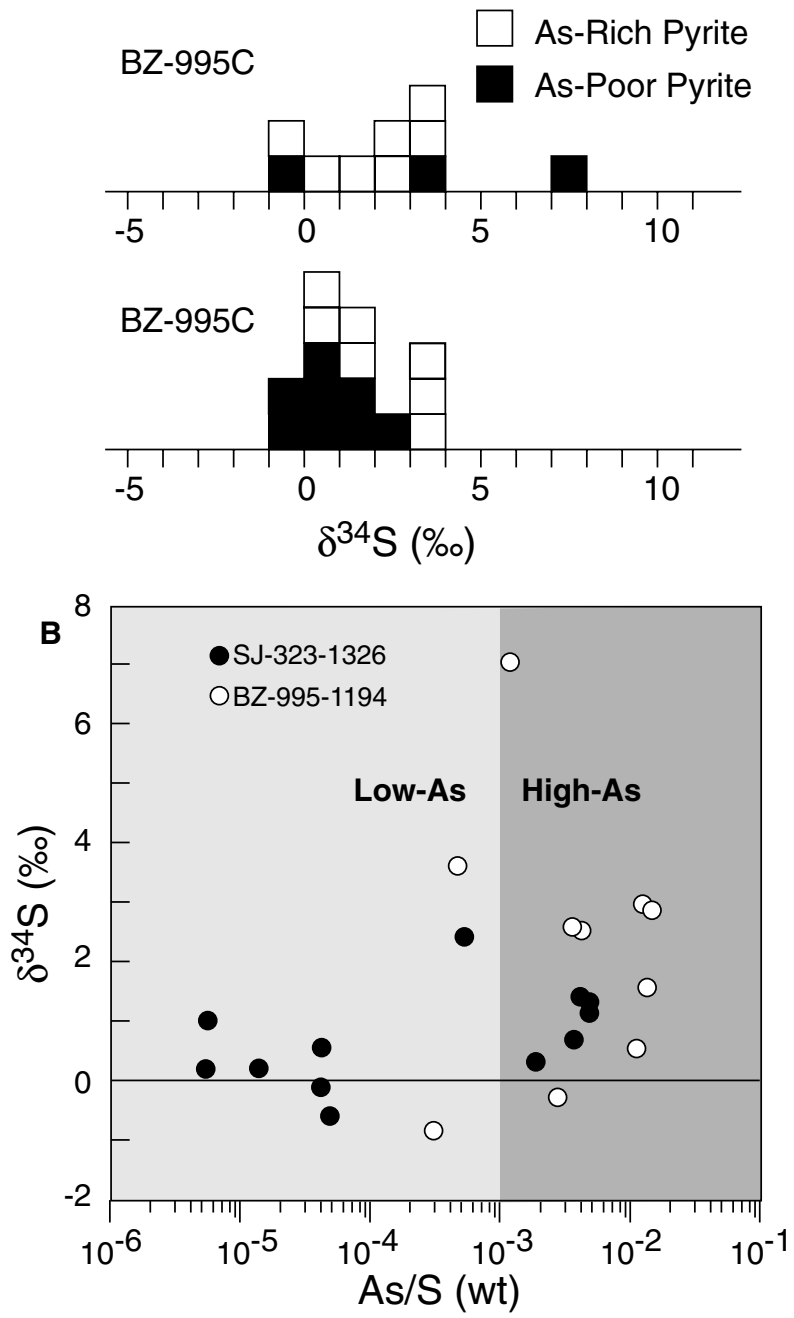

Fig. 5 a Histograms showing $\delta^{34} \mathrm{~S}$ values for arsenian pyrite (determined by SIMS methods) and realgar and orpiment (determined by analysis of hand-picked separates), both from the Screamer section of the Betze-Post-Screamer deposit, and b Relation between $\mathrm{As} / \mathrm{S}(\mathrm{wt})$ and $\delta^{34} \mathrm{~S}$ values in SIMS analyses of arsenian pyrite

deposited arsenic sulfides had $\delta^{34} \mathrm{~S}$ values of 9 to $14 \%$ is similar to that estimated in earlier studies, this range of values differs greatly from the $0 \%$ o that we estimate above for sulfur in the pyrite-forming solutions. Thus, whereas the earlier estimates of the isotopic composition of sulfur in fluids that formed arsenian pyrite and arsenic sulfides converged on a single isotopic composition for sulfur throughout deposition of the entire paragenesis, our new estimates require a major change in
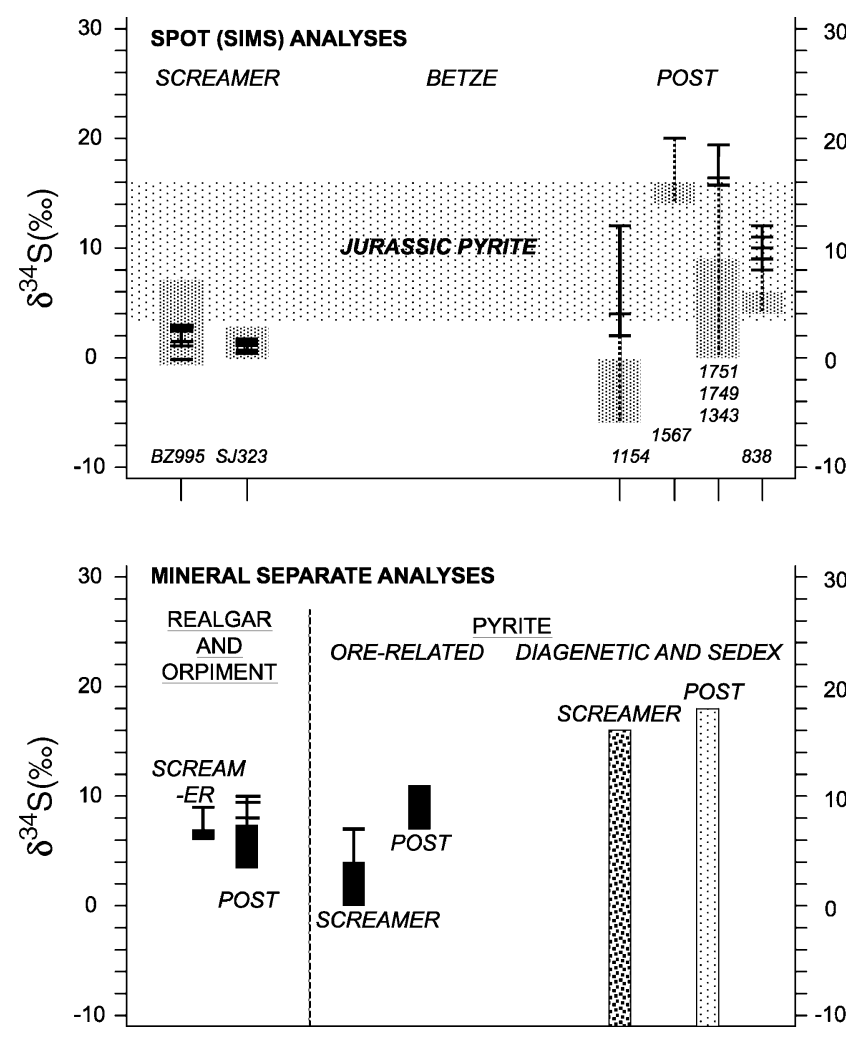

Fig. 6 Variation in $\delta^{34} \mathrm{~S}$ values of arsenian pyrite from Screamer (this study) and Post (Arehart et al. 1993a) parts of the Betze-PostScreamer deposit. Also shown, along left margin are $\delta^{34} \mathrm{~S}$ values for pyrite leachates from samples containing less than $200 \mathrm{ppb} \mathrm{Au}$ (Kesler et al. 2003a) and hand-picked separates of realgar and orpiment (this study) at Screamer, as well as exhalative sulfides in the Carlin area (Emsbo et al. 2003)

isotopic composition from about $0 \%$ during deposition of arsenian pyrite to about $10 \%$ or more during deposition of arsenic sulfides.

Although a mineralizing process involving no change in the isotopic composition of sulfur throughout the paragenesis is attractive in its simplicity, it appears to contradict phase equilibrium limitations in the $\mathrm{Fe}-\mathrm{As}-\mathrm{S}$ system. The location of arsenian pyrite, the key mineral in Carlin-type deposits, in the $\mathrm{Fe}-\mathrm{As}-\mathrm{S}$ system has not been determined experimentally (Clark 1960). However, it should coincide in part or completely with the field occupied by native arsenic plus pyrite, which are the phases that would form if arsenian pyrite decomposed. The fact that native arsenic is very rare in Carlin-type deposits suggests that arsenian pyrite occupies most of the native arsenic + pyrite field. Whether arsenian pyrite is stable or metastable within this field is not known, but the disappearance of the arsenic field above about $300^{\circ} \mathrm{C}$ suggests that arsenian pyrite will be rare above this temperature, a relation that agrees with its geologic distribution.

As can be seen in Fig. 7, paragenetic sequences that start with arsenian pyrite and end with orpiment require constant or increasing $f \mathrm{~S}_{2}$. Formation of arsenian pyrite at the uppermost limit of temperatures estimated for 


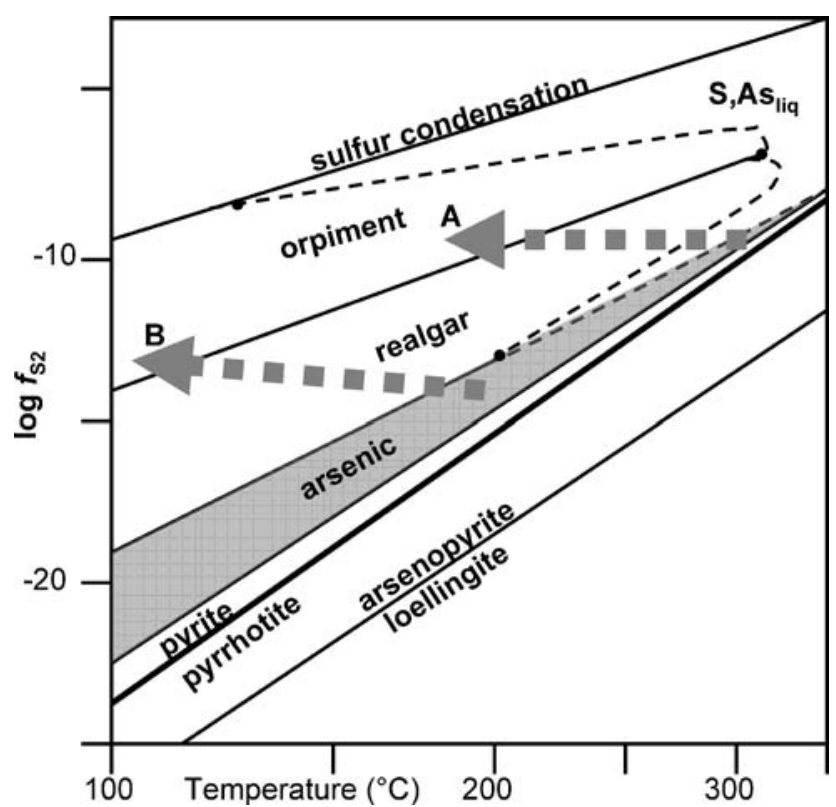

Fig. $7 \log f \mathrm{~S}_{2}-T$ diagram showing stability relations for minerals in the $\mathrm{Fe}-\mathrm{As}-\mathrm{S}$ system. Field for arsenian pyrite is shown here in the stability field commonly shown for native the assemblage As + pyrite because these would be the phases present if arsenian pyrite were not present. Exactly what part of this field is occupied by arsenian pyrite and whether this is a field of stability or metastability is unclear. Numbered arrows show paths through $T-X$ space discussed in the text

arsenian pyrite, about $300^{\circ} \mathrm{C}$, would require constant $f \mathrm{~S}_{2}$ and result in formation of orpiment at about $200^{\circ} \mathrm{C}$ (Path A, Fig. 7), slightly higher than depositional temperatures estimated from fluid inclusion data (J. Groff unpublished data; Simon et al. 1999; Hofstra et al. 2000). If depositional temperatures for arsenian pyrite are decreased to levels of $200^{\circ} \mathrm{C}$, increasing $f \mathrm{~S}_{2}$ with decreasing temperature is required to permit formation of orpiment before unrealistically low temperatures of about $100^{\circ} \mathrm{C}$ (Path B, Fig. 7).

Because arsenian pyrite is widespread in Carlin-type deposits, any fluid buffered by the rock would follow the realgar-arsenian pyrite boundary with decreasing temperature, making it impossible to reach the orpiment field without increasing $f S_{2}$ of the fluid. For fluids dominated by reduced sulfur in the form of $\mathrm{H}_{2} \mathrm{~S}$, an increased $f \mathrm{~S}_{2}$ requires higher total sulfur contents for the mineralizing fluid. Thus, the paragenetic sequence requires either that significant sulfur was added to the original fluid in order for it to deposit orpiment, or that arsenian pyrite and realgar-orpiment were formed by two different fluids, the second of which contained more sulfur than the first. Furthermore, comparison of sulfur isotope systematics and phase equilibria in the $\mathrm{Fe}-\mathrm{As}-$ $\mathrm{S}-\mathrm{O}-\mathrm{H}$ system shows that no changes in temperature and $f \mathrm{O}_{2}$ can produce the observed paragenetic sequence from arsenian pyrite to realgar to orpiment from a fluid with a single, unchanging sulfur isotopic composition (Ohmoto 1972; Ohmoto and Rye 1979; Heinrich and
Eadington 1986). Thus, the second contribution of sulfur had a different isotopic composition from the first. Our estimates reported here indicate that the first contribution of sulfur had a $\delta^{34} \mathrm{~S}$ value of about $0 \%$ compared to about $10 \%$ for the second.

\section{Sulfur isotope composition and sources of Carlin-type ore fluids}

Although additional data are needed, it appears likely that the paragenetic change in sulfur isotope compositions observed in this study is a general feature of Carlin-type deposits. In the only other detailed SIMS study of sulfur isotope geochemistry in a large Carlin-type deposit, Cline et al. (2002, 2003) reported that "goldbearing pyrite" from the Getchell mine has $\delta^{34} \mathrm{~S}$ values of -1 to $3 \%$ and that later arsenic sulfides have higher $\delta^{34} \mathrm{~S}$ values that require sulfur from a second source, exactly the same pattern observed at Betze-Post-Screamer.

This change is sulfur isotope composition of the mineralizing fluid with time probably reflects a change from an early magmatic to a later sedimentary source for the sulfur in Carlin-type deposits. Porphyry copper mineralization at Bingham, Utah, and Battle Mountain, Nevada, which is coeval with at least some of the Carlintype depostis, has $\delta^{34} \mathrm{~S}$ values near $0 \%$ (Bowman et al. 1987; Tosdal 1998; Hofstra and Cline 2000) and similar intrusions might have been the source for early ore fluids in Carlin-type deposits. Later fluids with higher $\delta^{34} \mathrm{~S}$ values might have come from intrusions contaminated by sulfur from diagenetic sulfides in the Paleozoic sedimentary rocks that host ore and through which the magmas ascended. Ohmoto and Goldhaber (1997) have shown that $\delta^{34} \mathrm{~S}$ values of felsic intrusions are more variable than originally assumed and that this reflects incorporation of wall rock sulfur. Vikre (2000) has shown that this type of contamination was widespread in Nevada and has estimated that up to $50 \%$ of the sulfur in Cenozoic-age ore deposits in this area was derived from Late Precambrian-Lower Cambrian terrigenous detrital sedimentary rocks. Although this sulfur is thought to have been assimilated by magmas that generated the deposits, it might also have been incorporated into circulating hydrothermal solutions during formation of the deposits.

It is unlikely that the second contribution of sulfur in Carlin-type systems was derived entirely from sedimentary or other non-igneous sources. Strong support for this is seen in the high arsenic, mercury and antimony contents of Carlin-type deposits and, in particular, in the later stages of mineralization. Whereas this suite of elements is a well-known product of magmatic systems, it is not a common product of fluids found in sedimentary basins. Although arsenic, and to a lesser extent antimony, are associated with fluids derived from prograde metamorphism, they are commonly not associated with mercury. In one of the few studies of the release of ore 


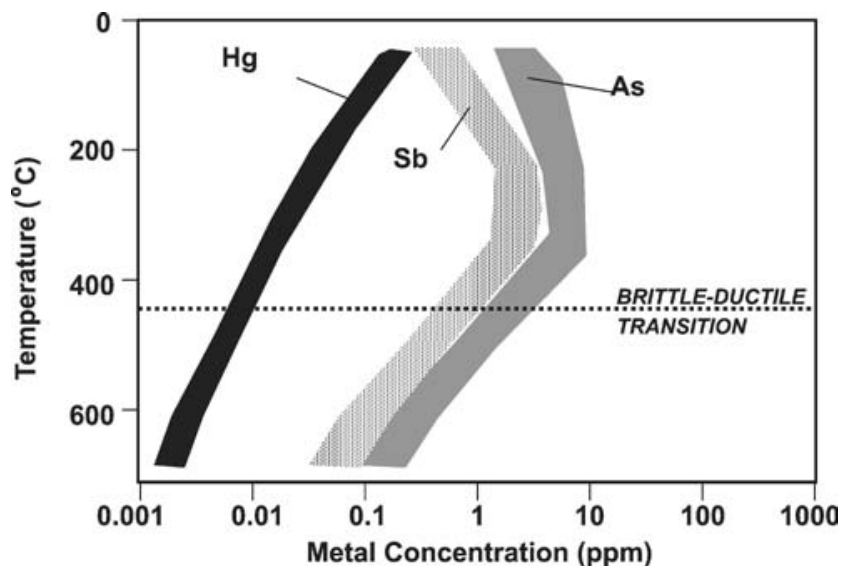

Fig. 8 Arsenic, antimony and mercury contents of samples of Otago Schist plotted against their peak metamorphic temperature (from Pitcairn et al. 2003) showing that mercury is released at much lower temperatures than arsenic and antimony

elements from prograde metamorphism, Pitcairn et al. (2003) have shown that mercury is released during the earliest stages of prograde metamorphism, whereas arsenic and antimony are released at higher temperatures (Fig. 8). This decoupling of mercury from arsenic and antimony is not in agreement with their strong correlation in Carlin-type deposits, where arsenian pyrite contains almost $1 \% \mathrm{Hg}$ (Stenger et al. 1998; Reich et al. 2005).

The probability of a magmatic source for Carlin-type ore fluids is further strengthened by comparisons of bulk ore compositions involving elements enriched in Carlintype deposits. Reliable data for a wide range of elements are available for sulfide facies ore at Screamer, Twin Creeks and Getchell (Stenger et al. 1998; Cail and Cline 2001; Kesler et al. 2003a). These data are plotted in Fig. 9 as ratios of the average concentration for each element in the deposit versus its average concentration in the crust. The plot shows that the most enriched elements in Carlin-type deposits are tellurium, gold and arsenic, followed by selenium, silver and mercury. The greater variation in the degree of concentration for mercury probably reflects the effects of boiling during ore deposition.

Further insights into the possibility of magmatic contributions to Carlin-type deposits can be gained by comparing these bulk compositions to those for highsulfidation epithermal deposits, which are widely considered to form from fluids with a strong magmatic contribution (Cooke and Simmons 2000). The best bulk compositional data for high-sulfidation deposits comes from the Pueblo Viejo district, for which geologic and stable isotope relations indicate an almost pure magmatic source for mineralizing fluids (Vennemann et al. 1993). As can be seen in Fig. 9, average compositions of the two main ore bodies at Pueblo Viejo are very similar to compositions of the Carlin-type deposits. The only significant difference is a higher content of base metals at Pueblo Viejo, which probably reflects periodic incursion of more saline magmatic fluids into high sulfidation systems (Vennemann et al. 1993; Cooke and Simmons 2000). Carlin-type deposits, which are probably farther from their magmatic source (Heinrich et al. 2004), would be less subject to this effect.

\section{Conclusions}

Our results indicate that sulfur in Carlin-type deposits is largely of magmatic origin with variable amounts of contamination from sulfur in Paleozoic sedimentary rocks. The sedimentary sulfur could have been delivered in formation fluids, but is more likely to have come from magmas that assimilated wallrock sulfur during ascent or from locally active hydrothermal solutions that leached sulfur from surrounding wall rocks. Variations in the degree of these contaminating processes probably account for the range of sulfur isotope compositions observed in Carlin-type deposits.
Fig. 9 Comparison of the bulk composition of Carlin-type and high sulfidation precious metal deposits (compiled from data of Kesler et al. (2003b), Cail and Cline (2001) and Stenger et al. (1998)

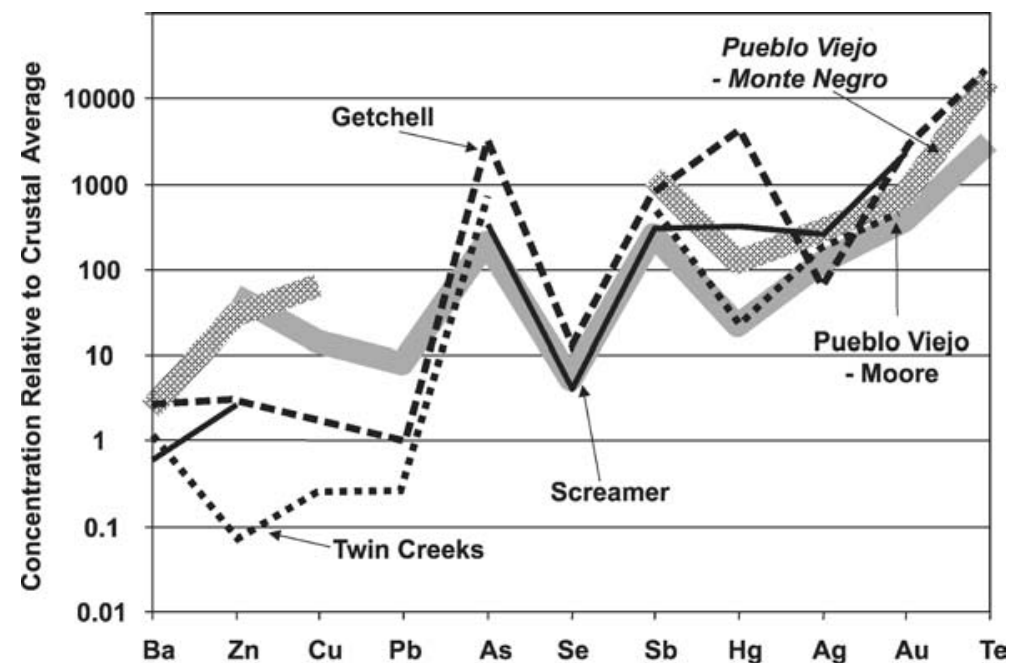


Acknowledgements We are grateful to Barrick Goldstrike Mines for access to samples and data on the Screamer system and to Keith Bettles, Eric Lauha, Pam Zohar, and Jeff Borhauer for geological guidance and discussion during all stages of the study. The project was supported by Barrick Goldstrike Mining Company and National Science Foundation grants EAR-9804963 and 0207273. Thanks also to Poul Emsbo for providing information on unpublished sulfur isotope analyses, Al Hofstra and Jean Cline for discussion of the geology and geochemistry of these deposits, John Fortuna for insights resulting from his work at Screamer, Dan Core for carrying out bulk sulfur isotope leachates on one of these samples, and Adrian Boyce, Georges Beaudoin and an anonymous reviewer for suggestions to improve the manuscript.

\section{References}

Arehart GB (1996) Characteristics and origin of sediment-hosted, disseminated gold deposits: a review. Ore Geol Rev 11:383-403

Arehart GB, Eldridge CS, Chryssoulis SL, Kesler SE (1993a) Ion microprobe determination of sulfur isotope variations in iron sulfides from the Post/Betze sediment-hosted disseminated gold deposit, Nevada, USA. Geochim Cosmochim Acta 57:1505-1519

Arehart GB, Foland KA, Naeser CW, Kesler SE (1993b) ${ }^{40} \mathrm{Ar} /{ }^{39} \mathrm{Ar}, \mathrm{K} / \mathrm{Ar}$ and fission -track geochronology of sedimenthosted disseminated gold deposits at Post-Betze, Carlin trend, northeastern Nevada. Econ Geol 88:622-646

Arehart GB, Chryssoulis SL, Kesler SE (1993c) Gold and arsenic in iron sulfides from sediment-hosted disseminated gold deposits: Implications for depositional processes. Econ Geol 88:171-185

Arehart GB, Chakurian AM, Tretbar DR, Christensen JN, MacInnes BA, Donelick RA (2003) Evaluation of radioisotopic dating of Carlin-type deposits in the Great Basin, western North America, and implications for deposit genesis. Econ Geol 98:235-248

Bakken BM, Einaudi MT (1986) Spatial and temporal relations between wallrock alteration and gold mineralization, main pit, Carlin gold mine, Nevada, U.S.A. In: MacDonald AJ (ed) Gold '86. Konsult International, Willowdale, pp 388-403

Bettles KH (1989) Gold deposits of the Goldstrike mine, Carlin trend, Nevada. Society Mining Engineers Preprint 89-158: $14 \mathrm{p}$

Bowman JR, Parry WT, Kropp WP, Cruer SA (1987) Chemical and isotopic evolution of hydrothermal solutions at Bingham, Utah. Econ Geol 82:395-428

Cail TL, Cline JS (2001) Alteration associated with gold deposition at the Getchell Carlin-type gold deposit, north-central Nevada. Econ Geol 96:1343-1359

Clark LA (1960) The Fe-As-S system-Phase relations and applications. Econ Geol 55:1345-1381

Cline JS, Stuart FM, Hofstra AH, Tretbar DR, Riciputi L, Premo W (2002) He, Nd, and stable isotope constraints on Carlin-type ore fluid components, Getchell NV, USA. Geol Soc America Program with Abstracts (gsa.confex.com/gsa/2002AM/final program/abstract $43002 . \mathrm{htm})$.

Cline JS, Stuart FM, Hofstra AH, Premo W, Riciputi L, Tosdal RM, Tretbar DR (2003) Multiple sources of ore-fluid components at the Getchell Carlin-type gold deposit, Nevada, USA. In: Eliopoulos DG (ed) Mineral exploration and sustainable development. Millpress, Rotterdam, pp 965-968

Cooke DR and Simmons SF (2000) Characteristics and genesis of epithermal gold deposits. Rev Econ Geol 13:221-244

Emsbo P, Hofstra AH, Lauha EA (2000) Jurassic auriferous polymetallic mineralization at the Goldstrike mine, Carlin trend, Nevada. In: Cluer JK, Price JG, Strusacker EM, Hardyman RF, Morris CL (eds) Geology and ore deposits: 2000: the Great Basin and Beyond: geological Society of Nevada Symposium Proceedings, May 15-18, 2000, B2

Emsbo P, Hofstra AH, Lauha EA, Griffin GL, Hutchinson RW (2003) Origin of high-grade gold ore, source of ore fluid components, and genesis of the Meikle and neighboring Carlin-type deposits, northern Carlin trend, Nevada. Econ Geol 98:1069-1107
Ferdock GC, Castor SB, Leonardson RW, Collins T (1997) Mineralogy and paragenesis of ore stage mineralization in the Betze gold deposit, Goldstrike mine, Eureka County, Nevada. Society of Economic Geologists, Guidebook Series 28:75-86

Heinrich CA, Eadington PJ (1986) Thermodynamic predictions of the hydrothermal chemistry of arsenic, and their significance for the paragenetic sequence of some cassiterite-arsenopyirte-base metal sulfide deposits. Econ Geol 81:511-529

Heinrich CA, Driesner T, Stefansson A, Seward TM (2004) Magmatic vapor contraction and the transport of gold from the porphyry environment to epithermal ore deposits. Geology 32:761-764

Hofstra AH (1997) Isotopic composition of sulfur in Carlin-type gold deposits: Implications for genetic models. In: Vikre P, Thompson TB, Bettles K, Christensen O, Parrat R (eds) Carlintype gold deposits field conference. Society of Economic Geologists Guidebook 28:119-129

Hofstra AH, Cline JS (2000) Characteristics and models for Carlin-type gold deposits. Soc Econ Geol Rev Econ Geol 13:163-220

Hofstra AH, Snee LW, Rye RO, Folger HW, Phinisey JD, Loranger RJ, Dahl AR, Naeser CW, Stein HJ, Lewchuk M (1999) Age constraints on Jerritt Canyon and other Carlin-type gold deposits in the western United States - relationship to midTertiary extension and magmatism. Econ Geol 94:769-802

Ilchik RP, Barton MD (1997) An amagmatic origin of Carlin-type gold deposits. Econ Geol 92:269-288

Kesler SE, Fortuna J, Ye Z, Alt JC, Core DP, Zohar P, Borhauer J, Chryssoulis SL (2003a) Evaluation of the role of sulfidation in deposition of gold: Screamer section of the Betze-Post Carlintype deposit, Nevada. Econ Geol 98:1137-1158

Kesler SE, Russell N, McCurdy K (2003b) Trace-metal content of the Pueblo Viejo precious-metal deposits and their relation to other high-sulfidation epithermal systems. Mineral Deposita 38:668-682

Kotlyar BB, Singer DA, Jachens RC, Theodore TG (1998) Regional analysis of the distribution of gold deposits in northeast Nevada using NURE arsenic data and geophysical data. In: Tosdal RM (ed) Contributions to the gold metallogeny of the northern Great Basin. U.S. Geological Survey Open-File Report 98-338:234-242

Kuehn CA, Rose AW (1995) Carlin gold deposits, Nevada: origin in a deep zone of mixing between normally pressured and overpressured fluids. Econ Geol 90:17-36

McSween Jr HY, Riciputi LR, Paterson BA (1997) Fractionated sulfur isotopes in sulfides of the Kaidun meteorite. Meteor Planet Sci 32:51-54

Ohmoto H (1972) Systematics of sulfur and carbon isotopes in hydrothermal ore deposits. Econ Geol 67:551-578

Ohmoto H, Goldhaber MG (1997) Sulfur and carbon isotopes. In: Barnes HL (ed) Geochemistry of hydrothermal ore deposits, 3rd ed. Wiley, New York, pp 517-612

Ohmoto H, Rye RO (1979) Isotopes of sulfur and carbon. In: Barnes HL (ed) Geochemistry of hydrothermal ore deposits, 2nd ed. Wiley, New York, pp 517-612

Paterson BA, Riciputi LR, McSween HY Jr (1997) A comparison of sulfur isotope ratio measurement using two ion microprobe techniques, and application to analysis of troilite in ordinary chondrites. Geochim Cosmochim Acta 61:601-610

Pitcairn IK, Ashley MR, Teagle DAH, Green DRH, German CR, Croudace IW, Brewer TS, Craw D (2003) Mobility of Hg, As, $\mathrm{Sb}, \mathrm{S}$ and $\mathrm{C}$ in a metamorphic belt: insights into the source of elements enriched in orogenic gold deposits, the Otago Schists, New Zealand. In: Eliopoulos DG (ed) Mineral exploration and sustainable development. Millpress, Rotterdam, pp 803-806

Radtkde AS, Rye RO, Dickson FW (1980) Geology and stable isotope studies of the Carlin gold deposit, Nevada. Econ Geol 75:641-672

Reich M, Kesler SE, Utsonumiya S, Palenik C, Chryssoulis S, Ewing R (2005) Solubility of gold in arsenian pyrite: an EMPA, SIMS and HRTEM investigation. Geochim Cosmochim Acta (in press) 
Ressell MW, Noble DC, Henry CD, Trudel WS (2000) Dike-hosted ores of the Beast deposit and importance of Eocene magmatism in gold mineralization of the Carlin trend, Nevada. Econ Geol 95:1417-1444

Riciputi LR (1996) A comparison of extreme energy filtering and high mass resolution techniques for the measurement of ${ }^{34} \mathrm{~S} /{ }^{32} \mathrm{~S}$ ratios by ion microprobe. Rapid Comm Mass Spec 10:282-286

Riciputi LR, Paterson BA, Ripperdan RL (1998) Measurement of light stable isotope ratios by SIMS: matrix effects for oxygen, carbon, and sulfur isotopes in minerals. Internat Jour Mass Spec 178:81-112

Seedorf E (1991) Magmatism, extension, and ore deposits of Eocene to Holocene age in the Great Basin-Mutual effects and preliminary genetic relationships. In: Geology and ore deposits of the Great Basin symposium geological society of Nevada, Reno, Nevada, Proceedings, pp 133-178

Sillitoe RH, Bonham HF (1990) Sediment-hosted gold deposits: distal products of magmatic hydrothermal systems. Geology 18:157-161

Simon G, Kesler SE, Chryssoulis S (1999) Geochemistry and textures of gold-bearing arsenian pyrite, Twin Creeks, Nevada: implications for deposition of gold in Carlin-type deposits. Econ Geol 94:405-422

Stenger DP, Kesler SE, Peltonen DR, Tapper CJ (1998) Deposition of gold in Carlin-type gold deposits: the role of sulfidation and decarbonatization at Twin Creeks, Nevada. Econ Geol 93:201216

Tosdal RM (1998) (ed) Contributions to the gold metallogeny of northern Nevada: U.S. Geological Survey Open-File Report 98-338:290 p

Vennemann TW, Muntean JL, Kesler SE, O’Neil JR (1993) Stable isotope evidence for magmatic fluids in the Pueblo Viejo epithermal acid-sulfate Au-Ag deposit, Dominican Republic. Econ Geol 88:55-71

Vikre PG (2000) Subjacent crustal sources of sulfur and lead in eastern Great Basin metal deposits. Geol Soc of America Bull 112:764-782

Ye Z, Kesler SE, Essene EJ, Zohar PB, Borhauer JL (2002) Relation of Carlin-type gold mineralization to lithology, structure and alteration: Screamer zone, Betze-Post deposit, Nevada. Miner Deposit 38:22-38 